\title{
Integration of French Lexicons in New Caledonian Javanese
}

\author{
Subiyantoro, Marsono, Wening Udasmoro \\ Universitas Gadjah Mada \\ Email: bravocraft@yahoo.com
}

\begin{abstract}
One of the peculiarities of New Caledonian is its French nuance, especially on the many French lexicons that either have integrated in the Javanese variant or are only borrowed. This study tries to answer the questions of what underlies the use of the French lexicons and how these lexicons integrated in New Caledonian Javanese. The data for this study were obtained through speech recordings as well as live interviews with a number of representative informants in New Caledonia. The data were collected through a qualitative manner in February 2013. Theories on language contacts, in particular with regards to loanwords, were implemented to analyze the data. The findings of this study indicate that the use of the French lexicons are caused by, firstly, the nonexistence of their equivalents in the recipient language (Javanese), secondly, Javanese speakers' motivation to distinguish themselves from other speakers, and the tendency of the Javanese to find the practical and easier way in dealing with the French lexicons.
\end{abstract}

Keywords: French, integration, Javanese, lexicons

\section{INTRODUCTION}

New Caledonian Javanese is a variant of the Javanese language that is spoken by Javanese community in New Caledonia. The language is characterized by the large number of French lexicons, some of which have integrated in the language and others are just borrowed with various reasons. The discourse of lexical integration cannot be separated from the borrowed words, which is termed emprunt in French or borrowings that is the more common English term. Borrowings are words borrowed from a donor language or "langue prêteuse" and have integrated in the recipient language or "langue emprunteuse" (see Thomason \& Kaufman, 1988: 37). Haugen (1972: 477) defines integration as the repeated use of the lingual units of a language in the spoken language (recipient language). The use of these lingual units has become commonplace because they have been borrowed in a relatively long period of time. In this regard, the intent of this study represented by its title is revealing the integration process of French loanwords in New Caledonian Javanese.

New Caledonia, a group of islands in the Pacific region and inhabited by different ethnicities, is a multilingual region where the majority of the population is bilingual. New Caledonian society, in addition to their mastery of the language according to their ethnicity, is obliged to be fluent in French that is a medium that is used in all the affairs of the state, economy, and education. One of the ethnic minorities living in the region is the Javanese who have inhabited the area since the end of the XIX century. Like other ethnic groups (except France), majority of the Javanese (aged 40 years and above) are actively bilingual. They speak Javanese for informal communication within the family or in their community sphere and speak 
French for formal and informal communication. Different from the older generation, the younger generation (aged 40 years and below) tends to only understand Javanese passively because they do not have the same opportunities as their parents did (Subiyantoro, 2014: 47).

As a dynamic entity, New Caledonian Javanese is evolving in the midst of other spoken languages in this multilingual region and growing in such a way that it has become increasingly different from the Javanese language in Java, Indonesia. Its contacts with other languages, especially French that is the official and the most dominant language, open more opportunities for linguistic elements of these languages to penetrate New Caledonian Javanese. Foreign words such as oleti meaning thank you from the Drehu language (spoken by the inhabitants of Lifou Island, east of Grande-Terre Island), nana meaning goodbye from Polynesian French used in Tahiti (there are many immigrants from Tahiti in New Caledonia), an English phrase no problem, and bonjour meaning good morning afternoon from French are commonly heard in conversations in New Caledonian Javanese.

As a medium of communication, this Javanese variant is used by Javanese descents in a community that speaks French as their official language. Therefore, it is not surprising that there are a number of French lexicons used in this language. French lexicons can be found in various areas. In the political sphere there are French words that are commonly used, such as parti "party", député "parliament", la mairie "town hall", liberté "freedom", éléction générale "general election". In the field of education one can find French words, such as école "school", lycée "high school", bourse "scholarship", ordinateur "computer". Meanwhile, in the culinary field French words commonly used in New Caledonian Javanese include $d u$ riz "rice", boulette "meatball", bière "beer", vin "wine", déjeuner "lunch", as seen in the following conversation between the researcher and (P1) with and informant, Mrs.K, (P2).

(01) P1: Bonjour

"Good morning"

P1: Urip Caledonia enak yo. Wonge sugihsugih.

"Living in Caledonia is nice, huh? The people are rich".
P2: Biyen urip rekoso. Jaman kontrak malheureux. Parce que kuli Jawa gak krasan, arep padha minggat. Simbahku, dikongkon londo, nggiring nganggo jaran. Ora oleh lunga sebabe ana kontrak. Il faut obéir le contrat. Yen wani karo londo iso mlebu prison. Saiki beda, ora ana kontrak, liberté. Mais seulement kudu ora sak geleme dhewe, kudu travailler. Travailler comme police, guru, gagnene dhuwur. Travailler quatre ans, iso tuku appartement, iso lungo neng nJawa. "Life used to be quite hard. The era of contracts was miserable. Javanese coolies did not enjoy their labor and they wanted to run away. My granpa was told by a Dutch to lead his way with a horse. They were not allowed to leave because they were still bound by the contract. It had to be complied with. If one dared to speak against the Dutch, he would be imprisoned. But now it's different, there isn't any contract anymore, people are free. But we cannot live our life as we like it. We need to work. Working as a policeman, teacher, the salary is very good. Working for four years, one can buy $\mathrm{n}$ apartment and visit Java."

The use of foreign lexicons (as seen in the above data) is a consequence of some of the following causes. The first cause is the absence of signifiant for some foreign words such as appartement "apartment", there are no equivalents to these words in New Caledonian Javanese. The second is that there is a certain motivation in using foreign words. In this language there are expressions and words that are equivalent to Javanese. On the other hand, this has caused the language to increasingly depart from their French counterparts, such as sugeng enjang (bonjour $=$ good morning), nyambut gawe (travailler $=$ go to work), sengsara (malheureux = miserable), and penjara (prison). However, because some speakers of New Caledonian Javanese have a certain motivation, they would say bonjour instead of sugeng enjang and travailler instead of nyambut gawe. The presence of French lexicons on one hand enriches the vocabulary of New Caledonian the linguistic characteristics of Javanese spoken in Java. Some of the words that have been imported from French have integrated and can be classified 
as borrowing. The use of these lingual units has become common because they have been borrowed in a relatively long period of time. The background of the problem in this study is the underlying factors for the integration of French lexicons as well as the process of this integration. The data in the forms of word lingual units obtained from the native speakers and representative informants residing in Nouméa and Koné in New Caledonia were recorded. The data collection was conducted qualitatively in February 2013.

\section{THE BORROWING}

A word is signe "sign", which is a combination of signifié "signified" and signifiant "signifier", or a fusion between what a speaker pictures in his mind (mental image) when he utters the word and its signifier or its material image that can be visual such as in the form of writing, a picture, or only a voice depending on the disclosure the concept either orally or in writing (De Saussure, 1993: 147).

A word that is imported from another language, either in their entirety or through a common modification is commonly called a borrowing. Haugen (1950) categorizes it into three types. The first category is loanword (l'emprunt integral), whose meanings and material forms are similar to those in the donor language. The second category is loanblend (l'emprunt hybride), which contain their original elements from the donor language and replacing elements from the recipient language. The last category is loanshift, which only contain the meanings of the loanwords as in the donor language. The last category is divided into two types, namely calque or word for word translation and semantic borrowing where only meaning is copied. In line with Haugen, Makri (2010: 209) classifies borrowings into three groups on the basis of their integration. These categories are emprunts directs "direct borrowings", emprunts modifiés "modified borrowings", and emprunts adaptés (adapted borrowings).

The inclusion of lexicons of a foreign language is not by chance, but rather motivated by certain motivations. At least there are five factors that trigger the creation of new words or meanings. The first factor is that this phenomenon more commonly occurs to relatively small languages. The four other factors are related to taboos, cultural changes occurring in the speech community, contacts with other languages, and any phonological changes (Pawley and Ross, 1995: 61). The inclusion of a lexicon of a foreign language can also be out of a sense of pride of the speaker when uttering the lexicon. It is not to mention if the lexicon belongs to a superior language. This prestige-related reason, although it is not expressed by its user, it often underlies the use of this foreign lexicon.

According to Bourdieu (1979), le goût (taste) is associated with social class distinctions. The taste in collecting works of art, choosing food, and following a lifestyle can determine or indicate one's social class. One's social class is not determined by social or economic capital but by his cultural capital. Having different tastes can distinguish a person from others. This can be a form of distinction that can make the person belong to a certain social class (see Udasmoro, 2014: 41). This distinction phenomenon can also occur in the use of foreign words, especially those belonging to languages spoken in developed countries. By using foreign lexicons that a speaker considers more prestigious, he wants to show that he has a different taste, which is higher than most people around him. In turns, this distinction can lead to the search for the construction of a new identity.

\section{FRENCH LEXICAL INTEGRATION}

Javanese migrants' contact with French began when the first wave of migrants set foot on New Caledonia in 1896 (see Muljono-Larue, 1996: 35). They were exposed to the lexicons of French for the first time when they signed their immigration papers, employment contracts, and so forth. The French lexicons they first encountered included contrat "contract", travail "work", obéir "adhere", signer "sign", respecter "honor", immigration "immigration", durée "period", date "date", and so forth. The penetration of French lexicons into Javanese intensified when Javanese children went to school, in which French is the language of instruction in all schools in New Caledonia. The surge of the French lexicons use seemed unstoppable with the decreasing number of active Javanese speakers in New Caledonia. In addition, the condition was worsened by the large number of incoming new lexicons to express new concepts 
such as ordinateur "computer", telecharger "download", and mel "email".

The collected data show that the French borrowing used in New Caledonian Javanese can be grouped into emprunts directs "direct borrowing" and emprunts modifiés "modified borrowing". Lexicons which fall into the category of emprunts directs include ticket [tike], école [ekol] "school", lycée [lise] high school", police [polis] "police", hôpital [opital] "hospital", and liberté [liberte] "liberty". The use of these emprunts directs can be observed in the following data obtained from an informant, Mrs. K.

(2) Yen supit biyen ana bong soko nJawa. Saiki kudu lunga neng hôpital.

"In the past when we wanted to have our sons circumcised, we could go to a bong (circumcision practitioner) coming from Java. Now we have to go to the hospital. "

(3) Saiki beda, ora ana contrat, liberté. Mais seulement kudu ora sak geleme dewe, kudu travailler.

"Now it is different, there is no contract, we are free. But we just can't live our life as we like it; we have to have a job."

The significant differences in phonemes and phones between the two languages have made the number of emprunts directs relatively low. These French lexicons were borrowed in their original forms in New Caledonian Javanese without changing both their signifiant and signifié. In other words, the mental and material aspect of the sign did not undergo changes. The emergence of emprunts directs was due to the fact that the speakers of New Caledonian Javanese had not had any difficulty in pronouncing these words. The phonemes forming these words are similar to those in the Javanese variant. The lexicons given as examples did not undergo phonetic, graphic, or morpho-syntax adjustment. This happened because from the beginning the speakers of this language did not experience difficulties in pronouncing the French lexicons. The signifiant in the form of sounds to pronounce the lexicons were not aliens to the speakers of the language because these sounds exist in Javanese. In terms of its graphics, New Caledonian Javanese is not a written language and, therefore, when Javanese speakers came across French lexicons they did not try to write them in accordance with the pronunciation rules of Javanese. They merely imitate the sounds produced by French native speakers.

The data show that the integration of the French lexicons mostly underwent some changes or modifications related to the elements of the lingual elements of the recipient language. The borrowings found are in the forms of signe that are signifiant or those whose material form has undergone a change from their original form but they still have signifié (meanings) similar to those of the original lexicons. This change can be phonetic or even morpho-syntactic in nature. Similar to other recipient languages of borrowings, pronunciation adjustments of the foreign lexicons to the pronunciation rules of the recipient language often take place. Phonetic adjustments can occur because they are desired, such as the existence of a rule stating that borrowings from foreign languages have to be adjusted in accordance with the pronunciation rules of the recipient language. In the case of New Caledonian Javanese, the pronunciation of French borrowings occurs spontaneously without any interference from any linguistic device.

In terms of phonology, both languages are significantly different. Javanese has 6 vowel phonemes, while French has 16 vowels comprising nasal and oral vowels. In addition, Javanese has 23 consonant phonemes while French has 20 consonant phonemes (see Molina Mejia, 2006: 16-18; Marsono, 2005: 23; Wedhawati, 2006: 65-66). These differences have an impact on the French loanwords. Not all of the French lexicons borrowed in New Caledonian Javanese can be pronounced exactly as native speakers of French pronounce them. Initially, the vowels/ $\tilde{a} \tilde{\varepsilon}$ œ $\tilde{\jmath}$ y $ø /$ and consonants $/ \int, 3$ в/ were among the phonemes that were difficult to be pronounced by Javanese speakers. Javanese people have difficulties in pronouncing French loanwords containing these phonemes such as in monsieur "mister", ordinateur "computer", seulement "only", bus "bus", chauffeur "driver", appartement "apartment", faux "false", and visage "face". In their attempt to pronounce these words as close as possible to how French native speakers pronounce them, speakers of New Caledonian Javanese try to make their best effort. The result is that 
these borrowings are pronounced with Javanese pronunciation. The French phonemes that are deemed difficult to pronounce are automatically replaced by phonemes whose pronunciations are familiar to them. Usually these substitute phonemes are produced in the same places and with the same manners of articulation as the places and manners of articulation of the original phonemes or at least close to those of the original phonemes. From the data that were collected the researcher discovered the following phonetic changes:

- $\quad$ A close-mid front vowel, / ø/, by speakers of New Caledonian Javanese is pronounced [ə], mid central vowel of French. The word ordinateur [ordinatøь] is pronounced [ordinatər] and monsieur [məsjø] is pronounced [məsə].

- $\quad$ The French middle vowel / y / is substituted with a back vowel [u]. The loanword bus [bys] is pronounced [bus] and figure [figyR] is pronounced [pigur].

- $\quad$ The French final nasal vowel [õ] becomes vowel + nasal velar consonant [oท]. The word appartement [apaRtmo] is pronounced [apartəmon], the word accident [aksidã] is pronounced [aksidon], ca dépend [sa depo] is pronounced [sadepэy], and the word prison [prizõ] is pronounced [prizon].

- The French voiceless labio-dental consonant $/ \mathrm{f} /$ is pronounced as a voiceless bilabial consonant $[\mathrm{p}]$. The word fini [fini] is pronounced [pini], éffaser [efase] is pronounced [epase], figure [figyR] is pronounced [pigur], and the lexicon la fin

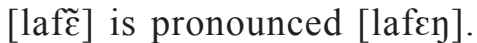

- $\quad$ The French voiced labio-dental consonant $/ \mathrm{v} /$ is pronounced $[\mathrm{w}]$. The word visage [viza3] is pronounced [wizaz] and the word Javanais [3avane] is pronounced [zawane].

- $\quad$ The French palatal-fricative consonant / $3 /$ is pronounced as alveolar fricative consonant $/ \mathrm{z} /$. The word visage [viza3] is pronounced [wizaz) and voyage [vaja3] is pronounced [vajaz].

- The French uvular trill consonant / R / is systematically pronounced as a Javanese alveolar trill $/ \mathrm{r} /$. The word ordinateur [ərdinatøь] is pronounced [ərdinatər] and the word malheureux [maløRø] is pronounced [malərə].

- The French fricative-palatal consonants / $\int /$ is pronounced as a dental fricative [s]. The word chauffeur [ ofø $\mathrm{R}]$ is pronounced [sopər],

Lingual modifications do not only occur at the level of phonetics but also at the level of morphosyntax. Most of the French borrowings are nouns and the rest comprises verbs and adjectives. In term of nouns there is some uniformity - most Javanese speakers in New Caledonia use them without conforming to French grammatical rules for nouns (genre and number are marked by an article). This is the underlying factor that in Javanese in New Caledonia most of the noun loanwords are spoken without being preceded by an article. Data (4) and (5) below are an excerpt expressed by an informant, Mr. T.

(4) Awake dhewe duwe livre Les Javanais du Caillou. "We have the book "Les Javanais du Caillou "

The loanword in this sentence, livre (book), is not preceded by an article, neither un (idefinite article) nor le (definite article), whereas in French the noun in a sentence must be accompanied by an article. In this regards, a number of noun loanwords have been adapted to the recipient language, New Caledonian Javanese. Therefore, these words are pronounced as how Javanese nouns are pronounced.

(5) Anaku wis tuku appartement. "My son has bought an apartment".

The word appartement, a singular masculine noun, should have been preceded by an article, either un or le, un appartement or l'appartement. However, in New Caledonian Javanese this word is often used without either one of the articles. The French noun integration by omitting French grammatical device, in this case the article, can also be caused by the Javanese speakers' tendency to simplify things (nggampangke in Javanese). After all, by not including an article their hearer can still understand the message they want to convey. Not all noun loanwords are used without their article. As seen in the following, nouns that are considered short are usually used with their article as seen in data (6), (7), and (8) expressed by an informant, Mr. V. (6) 'L'avion ara mangkat parce que mesine 
rusak". "The plane did not leave because its engine was broken".

(7) Ca y est wis la fin. "It's done "

In these examples, there are two complete nouns with their article ( $l$ ' for avion, and la for fin). The use of the article la in la fin (end) is influenced by Javanese that tends to double the syllable of one-syllable words, such as in the word mbok (mother) this word is usually pronounced [əmbək]. Meanwhile in the sample (8) the use of the article la in la mairie [lameRi] "town hall" is most likely aimed to avoid confusion with the Javanese word meri [meri] which means jealous.

(8) Neng kene marriage iso neng la mairie iso disadati. "Here, a wedding ceremony can be held in the town hall or through nikah "urfi (a "customary" Sunni Muslim marriage contract that is not registered with state authorities).

In relation to nouns, there is an interesting phenomenon that French noun loanwords are modified by the addition of the Javanese's suffix $-e$. This can be seen in data (9) below. This is an utterance expressed by Mr. $\mathrm{H}$ (an informant) when he was explaining custom-related ceremonies.

(9) Ambengan kuwi ingkung, sego golong, Jajan pasar. La fin e [lafen,e] dikei wajib (duwit): nggo nutupi kekurangan, belanja dhewe-teng dhewe teng pasar.

"Ambengan is whole chicken, golong rice, and market munchies. Wajib (some money) is put on its cover; to cover any shortfall, we must do our own shopping at the market".

In data (9) the French loanword la fin e meaning cover or end (Javanese speakers pronounce it [lafen,e]) is derived from a French noun la fin (end) followed by a Javanese suffix $-e$. In addition to this suffix, the Javanese suffix $-e$ can also be found in other French noun loanwords, such as the French noun la fête "party" that is added with the Javanese suffix - an becoming lafetan "party". This method is analogous to a Javanese word slamet + suffix an thus it becomes slametan. This phenomenon is termed a hybrid loanword in a previous study (see Subiyantoro, 2014: 52).

Similar to the case of the French nominal loanwords, French adjective loanwords also deviate from the grammatical rules of the donor language
(French) and are adapted to the grammatical rules of Javanese. The French adjective pressé meaning 'in a hurry' is used with an auxiliary verb être, but as a loanword in Javanese this is not the case, as shown in the data (10). I encountered this linguistic phenomenon when Mr. T did not allow me to go home.

(10) Ora pressé mulih. Déjeuner dhisik. "Do not rush home, eat lunch first."

French native speakers would say "Je suis pressé " (I'm in a hurry) or "Tu es pressé" (You are in a hurry). However, the speakers of Javanese in New Caledonia would utter the adjective pressé without using the auxiliary verb être. They would use it in sentences such as aku pressé (I'm in a hurry) or kowe pressé (You are in a hurry).

With regards to verbs, conjugation rules in French are not complied with in the case of French verb loanwords in Javanese. Conjugation is one of the difficulties for Javanese speakers to speak French. Therefore, the adjustment of French verbs in Javanese has made a significant difference between the verbs in their origin use in French and as loanwords in Javanese. In Practice Javanese speakers tend to find the easier way to use these verbs. As a result they only pronounce the infinitives and do not conjugate them. Consider the following sentences, expressed by Mrs. K.

(11) Awake dhewe nek ora travailler dur, ora iso reussir. "We need to work hard, otherwise will not succeed".

In French the word travailler (to work) should be conjugated as travaillons because the subject is awake dhewe "we", the 3 rd person plural. Likewise, the data below show the adjustment of the French verb manger (eat). If conjugated, as French grammatical rules require, the verb manger should be spoken mangez by Speaker 1 because the subject of the sentence is vous "you", a second person. Using vous as a subject requires a polite utterance. In relation to Speaker 2, the verb manger should be spoken as mange because the subject of the sentence is $j e$ "I" (first person singular). Observe a conversation between two young people of Javanese Diaspora recorded in February 2013.

(12) S1: Mau ce matin manger apa?? "This morning, what did you eat?"

S2: Manger du riz. "I ate rice"

In addition to the infinitive form, there are French 
verb borrowings that have been modified by adding the Javanese suffix $-e$ (see Subiyantoro, 2013: 52). As far as the researcher is concerned, although this method is not productive, this, apparently, has given its own uniqueness. Let us consider the following data (a narration told by Mrs. K):

(13) Travailler comme police, guru, gagnerne dhuwur. Travailler quatre ans, iso tuku appartement, iso lungo neng nJawa. "Working as a policeman, teacher, the salary is high. Working four years, one could buy an apartment, could go to Java."

This phenomenon occurred because initially Javanese speakers did not understand the grammatical rules of French so they tend to simplify when using the word gagner. They analogized the use with the use of the Javanese word bayarane (bayaran $+e$ ) which means the salary. The word gagnerne comes from gagner + $e$, which means to receive a salary.

In addition to the above types of loanwords, the researcher also discovered conjunctional loanwords, such as après (afterwards), et puis (then), and parce que (because). Data (14) and (15) are excerpts from longer talks produced by $\mathrm{Mr}$. V and $\mathrm{Mr}$. T.

(14) Awake dhewe oleh mangan neng aéroport Sydney, mais les autres ora, parce que awake dhewe client Quantas.

"We got meal at Sydney airport, but others didn't. This is because we were all Qantass passengers."

(15) Lekas-lekasane anak kawin disadati, supaya dudu anak jadah. Diteruske brokohan, puis selapanan. Bayi lahir dianake amongamong kanggo sing ngemong jabang bayi. Selapanan, ensuite apa kuwi jawane décendre sur terre"?

"In the beginning, the girl was married through nikah 'urfi, so that the child didn't become an illegitimate child. And then proceeded with brokohan and selapanan. When the baby was born, among-among was held for the ones helping to take care of the baby. Selapanan, then what is the one that placing the baby on the ground?"

Conjunctions of mais (but), parce que (because), puis (then), and ensuite (then/afterward) shown by the above data are conjunctions of French that have integrated in Javanese spoken in New Caledonia. As far as the researcher observed, Javanese speakers in this region rarely use the Javanese conjunctions including banjur (then/afterward), sebab (because), terus (after that). Nowadays they are more accustomed to using the above French conjunctions. This is because Javanese speakers in New Caledonia speak French much more frequently than Javanese. This has impacted on the use of lexicons that are highly frequently used including conjunctions.

Intercultural contacts could allow French as the donor language to introduce new concepts (signifié) accompanied by their material forms (signifiant) including pronunciations, images, or texts. The word ordinateur (computer) was introduced to Javanese spoken in New Caledonia along with its concept or its mental image. The inclusion of this word is accompanied by other lexicons associated with computers such as écran "computer screen", souris "mouse", portable "laptop", batterie "battery", and clavier "keyboard". These lexicons were just borrowed the Javanese speakers because they do not have their equivalents in Javanese and Javanese speakers feel that they need these lexicons.

One of the causes of the integration of a number of French lexicons in Javanese is that Javanese speakers are not aware that their language actually has lexicons synonymous to the French loanwords. These loanwords include orchidée "orchid", lycée agricole "agriculture vocational school", and chauffeur "driver", as seen in the utterance expressed by Mrs. K below.

(16) Aku biyen neng Lycée agricole. Saiki aku chauffeur. Ibu Sudarni dodol kembang orchidée.

"I studied at an agriculture vocational school. Now I'm a driver. Mrs Sudarni sells orchids ".

When a number of the Javanese left the island of Java to find jobs in New Caledonia (except those arriving 1970s), the orchid orchidée was not so well known in Java. Therefore, it was predicted that the word anggrek (orchid) was not carried by the Javanese immigrants and, therefore, today Javanese speakers in New Caledonia do not recognize this word. This is also true for the term Lycée agricole, the term SMK Pertanian (agriculture vocational 
school) that is the equivalent to the term only emerged in the 65's (the first of SMK Pertanian was established in 1965 in Java).

The use of a French lexicon by a Javanese speaker in New Caledonia can also be triggered by a certain motivation even though they know that Javanese has a word (signifiant) which refers to the concept of the French word. This speaker consciously uses the French word in the hope that he can raise their prestige amongst the community. French is regarded as a prestigious language because it is the language of the government, an official language in France include New Caledonia, one of the major languages in Europe, and one of the official languages of the United Nations. Some people believe that if they use French lexicons or French in a broader sense, they can consider themselves to have a gout (taste) different from other speakers so that this can take them to a higher social level. Using French or only its lexicons is also away for people to distinguish themselves from other speakers. This can be seen when a Javanese diaspora in New Caledonia is in a store in Yogyakarta asks the attendant using ngoko Javanese. The attendant would be stunned and reply: "Bapak soko endi kok ora nganggo bahasa Indonesia?" "Where are you from, Sir, how come you don't speak Bahasa Indonesia?"). The man would reply: "Aku ora iso bahasa, ning iso bahasa Prancis" ("I don't speak Indonesian, but I speak French). This reply shows a distinction. He actually wants to say that he is Javanese but he speaks French, while the attendant only speaks Javanese and Indonesia. In addition, the use of French or its lexicons can also be a form of new identity search. These speakers are not like Javanese living in Java Island, but they are not similar to the first Javanese people who landed in New Caledonia. They have their own habitus formed through a lengthy process that has made them who they are today - they are Javanese, New Caledonian, and French depending on the question at hand.

When speakers of New Caledonian Javanese feel inclined to utter inappropriate words, such as swear words, they would try to find substitutes that are less strong or offensive. They usually find these substitutes in French as they believe that French lexicons are less strong than the offensive Javanese words. The French lexicons chosen as euphemisms include those referring to the sexual organs or sexual activities. Words such as bourrer (to have a sexual intercourse), and avoir la canne (to have an erection) are considered more neutral than their equivalents in Javanese.

\section{CONCLUSION}

The influence of French as the dominant language in New Caledonia is reflected in the large number of its lexicons that have integrated in Javanese. This integration is at least underlain by two phenomena. The first phenomenon is that the preference of using French lexicons can be a form of distinction performed by the speakers of Javanese in New Caledonia. This is the motivation to distinguish oneself from other speakers and to show that the speaker has different tastes that can raise his prestige. With this prestige it is expected he can belong to a higher social level.

The second phenomenon underlying this integration is that Javanese speakers in New Caledonia tend to perform the easier way when interacting using Javanese with each other. The facts that they master French and Javanese and that French is more frequently used allow these Javanese speakers to be more familiar with French. Therefore, some number of them master more French lexicons than Javanese lexicons. This is especially true in the case of lexicons expressing messages associated with new concepts. Consequently, when Javanese speakers come across difficulties finding words when interacting, they will immediately select and use French lexicons that they are familiar with.

\section{REFERENCES}

Bourdieu, Pierre (1979). La Distinction: Critique Sociale du Jugement. Paris: Les Editions de Minuit.

De Saussures, Ferdinand (1975). ELement de linguistique Generale. Paris: Payot.

Haugen, Einar (1950). "The analysis of linguistic borrowing." Language, vol 26: 210-231.

(1972). Direction in Modern Linguistics. Chicago: University Press.

Molina Meiha, Jorge Mauricio (2006/2007). Diagnostique et Correction des Erreurs de Prononcition en FLE des Apprenants Hispanophones. Tesis Master. Université 
Stendhal-Grenoble.

Makri, julie (2010). Les Procédés de Creation Lexicale Regis par l'emprunt en Espagnol Péninsulaire Contemporain. Cahiers de lexicologie, 97-109.

Marsono (2005). Fonologi Bahasa Jawa dan Bahasa Jawa Kuna. Laporan Penelitian FIB Universitas Gadjah Mada.

Muljono-Larue, Fidayanti (1996). L'Immigration Javanaise en Nouvelle Calédonie de 1896 à 1950. Nouméa: CTRDP-AINC.

Subiyantoro (2014). Survival Strategies of The Javanese Language in New Caledonia. Jurnal
Humaniora, 26, 43-55.

Thomason, Sarah Grey. \& Kaufman, Terrence (1988). Language contact, creolization, and genetic linguistics. Berkeley: University of California Press.

Udasmoro, Wening (2014). Konstruksi Identitas Remaja dalam Karya Sastra. Yogyakarta: Program Studi Sastra Prancis Fakultas Ilmu Budaya Universitas Gadjah Mada.

Wedhawati, et al. (2006). Tata Bahasa Jawa Mutakhir. Yogyakarta: Kanisius. 